\title{
Deep Thermohaline Circulation Across the Closure of the Central American Seaway
}

\author{
NAZIK ÖĞRETMEN ${ }^{1}$, RALF SCHIEBEL ${ }^{1}$, KLAUS PETER \\ JOCHUM $^{1}$, BRIGITTE STOLL ${ }^{1}$, ULRIKE WEIS ${ }^{1}$, JANNE \\ REPSCHLÄGER $^{1}$, ANNA JENTZEN ${ }^{1}$, STEVE GALER ${ }^{1}$ AND \\ GERALD H. HAUG ${ }^{1,2}$ \\ ${ }^{1}$ Max Planck Institute for Chemistry \\ ${ }^{2}$ ETH Zurich \\ Presenting Author: n.ogretmen@mpic.de
}

The closure of the Central American Seaway (CAS) resulted in changes of ocean-climate dynamics since the late Miocene following the uplift of northern Andes. Reconstructing the bottom-water temperatures (BWTs) of the Caribbean Sea illustrates feedbacks of the closure on the ocean-climate system including deep-water dynamics of the Caribbean Sea. In this study, femtosecond-LA-ICP-MS method was applied on single foraminifer specimens to investigate the trace element/Ca composition for long-time scales. $\mathrm{Mg} / \mathrm{Ca}$-derived BWTs of the Plio-Pleistocene Caribbean Sea from well-preserved epibenthic Cibicidoides wuellerstorfi are interpreted together with $\mathrm{Sr} / \mathrm{Ca}$ as an indicator of continental input for the time interval between 5.2 and 2.2 Ma[1]. Our results indicate that changes in the circulation of deep-water masses during the CAS closure developed in four main time-intervals: I) between 5.2-4.1 Ma at BWT around $1.1^{\circ} \mathrm{C}$, II) $4.1-3.2 \mathrm{Ma}$ at BWT $\sim 2.1^{\circ} \mathrm{C}$, III) $3.2-2.7$ $\mathrm{Ma}$ at BTW $\sim 2.7^{\circ} \mathrm{C}$, and IV) $2.7-2.2 \mathrm{Ma}$ at BWT $\sim 2.1^{\circ} \mathrm{C}$. Gradually increasing temperatures from 5.2 Ma until 2.7 Ma well correlate with previous sea-surface temperatures from the planktic foraminifer Neogloboquadrina dutertrei[2], and correspond to restricted inflow of fresh Pacific waters into the Caribbean Sea due to the CAS shoaling and intensification of thermohaline circulation. The gradual decrease of the BWTs following 2.7 Ma may have resulted from the onset of Northern Hemisphere Glaciation. In addition, $\mathrm{Sr} / \mathrm{Ca}$ values reveal that gradually escalating terrigenous input until $2.7 \mathrm{Ma}$ are most likely related to the increased river discharge in response to the Andean uplift and freshening of the surface water column. In contrast, new $\mathrm{Na} / \mathrm{Ca}$ data of $C$. wuellerstorfi indicate enhanced salinity of the bottom-waters as a driver of intensified thermohaline circulation during the late Pliocene warmth.

\section{References}

[1] Öğretmen, N, Schiebel, R., Jochum, K.P., Stoll, B., Weis, U., Repschläger, J., Jentzen, A., Galer, S., Haug, G.H., 2020. Deep Thermohaline Circulation Across the Closure of the Central American Seaway. Paleoceanogr. Paleoclimatology 35, e2020PA004049.

[2] Steph, S., Tiedemann, R., Prange, M., Groeneveld, J., Schulz, M., Timmermann, A., Nürnberg, D., Rühlemann, C., Saukel, C., Haug, G.H., 2010. Early Pliocene increase in thermohaline overturning: A precondition for the development of the modern equatorial Pacific cold tongue. Paleoceanography 25. 